\title{
Respiratory symptoms and bronchial responsiveness in lifeguards exposed to nitrogen trichloride in indoor swimming pools
}

\author{
N Massin, A B Bohadana, P Wild, M Héry, J P Toamain, G Hubert
}

Institut National de Recherche et de Sécurité, INRS, Service

d'Épidémiologie, Vandoeuvre-lès-Nancy,

France

N Massin

$P$ Wild

J P Toamain

Institut National de la Santé et de la

Recherche Médicale, INSERM, Unité 420, Epidémiologie Santé Travail,

Vandoeuvre-lès-Nancy, France

A B Bohadana

Institut National de Recherche et de

Sécurité, INRS,

Evaluation et

Prévention du Risque

Chimique,

Vandoeuvre-lès

-Nancy, France

M Héry

G Hubert

Correspondence to:

Dr N Massin, INRS, Service

d'Épidémiologie, BP 27,

54501

Vandoeuvre-lès-Nancy,

Cedex, France. Tel: 003383

502000 ; Fax: 00338350

2015.

Accepted 25 November 1997

\begin{abstract}
Objectives-To measure the levels of exposure to nitrogen trichloride $\left(\mathrm{NCl}_{3}\right)$ in the atmosphere of indoor swimming pools and to examine how they relate to irritant and chronic respiratory symptoms, indices of pulmonary function, and bronchial hyperresponsiveness to methacholine in lifeguards working in the pools.

Method-334 lifeguards (256 men; 78 women) recruited from 46 public swimming pools $(n=228)$ and 17 leisure centre swimming pools $(n=106)$ were examined. Concentrations of $\mathbf{N C l}_{3}$ were measured with area samplers. Symptoms were assessed by questionnaire and methacholine bronchial challenge (MBC) test by an abbreviated method. Subjects were labelled MBC+ if forced expiratory volume in one second $\left(F E V_{1}\right)$ fell by $\geqslant 20 \%$. The linear dose-response slope was calculated as the percentage fall in $\mathrm{FEV}_{1}$ at the last dose divided by the total dose given.

Results-1262 samples were taken in the 63 pools. Mean $\mathrm{NCl}_{3}$ concentrations were greater in leisure than in public pools. A significant concentration-response relation was found between irritant eye, nasal, and throat symptoms-but not chronic respiratory symptoms-and exposure concentrations. Among women, the prevalence of $\mathrm{MBC}+$ was twice as great as in men. Overall, no relation was found between bronchial hyperresponsiveness and exposure.

Conclusions-The data show that lifeguards exposed to $\mathrm{NCl}_{3}$ in indoor swimming pools are at risk of developing irritant eye, nasal, and throat symptoms. Exposure to $\mathrm{NCl}_{3}$ does not seem to carry the risk of developing permanent bronchial hyperresponsiveness, but this association might have been influenced by self selection. The possibility that subjects exposed to $\mathrm{NCl}_{3}$ are at risk of developing transient bronchial hyperresponsiveness cannot be confidently ruled out.
\end{abstract}

(Occup Environ Med 1998;55:258-263)

Keywords: indoor swimming pools; lifeguards; irritation; respiratory symptoms; nitrogen trichloride

World wide, many millions of people take pleasure in swimming regularly in swimming pools. Traditionally, pool attenders face the risk of developing dermatological diseases due to expo- sure to micro-organisms - for example, $\mathrm{Myco-}$ bacterium balnei, Mollusculum contagiosumfound in the pool water or in the surrounding area. ${ }^{1}$ Also, those attending indoor pools are at risk of inhaling aerosols of microorganisms - for example, Legionella pneumophila-or chemical substances released by the reaction between disinfecting agents added to the pool water and organic matter of human origin.

In 1993, the departments of several health insurance agencies in France that deal with occupational diseases reported unusually high rates of ocular and respiratory irritation among lifeguards employed at various indoor pools that used chlorine as a disinfecting agent. After this observation, exposure was monitored by chemists from our institution, and showed that among the possible irritants present in the air of the pools only the chloramines were detected in non-negligible quantities. Moreover, nitrogen trichloride $\left(\mathrm{NCl}_{3}\right)$ was the main chloramine present. ${ }^{2}$ This exposure survey showed also that the concentrations of $\mathrm{NCl}_{3}$ were much higher in the leisure centre pools than in the public pools. Furthermore, the spontaneous complaints of irritant symptoms seemed to be correlated with measured exposure concentrations. Consequently, the Fédération Nationale des Maîtres-nageurs Sauveteurs (FNMS) of France asked our team to investigate the possibility of a causal relation between the concentration of $\mathrm{NCl}_{3}$ and the prevalence of these symptoms.

The present study was carried out to determine the frequency of ocular and respiratory symptoms in lifeguards working in indoor pools and to examine the extent to which they were related to the measured concentrations of $\mathrm{NCl}_{3}$ in the pool areas. Additionally, we also attempted to better understand how these variables relate to bronchial responsiveness to methacholine.

Subjects and methods

The study was a cross sectional survey of 334 lifeguards recruited from 46 public swimming pools $(n=228)$ and 17 leisure centre swimming pools $(n=106)$. To increase the exposure range and thus the power of the study, the first swimming pools selected were the swimming pools within leisure centres. In a second stage all the public swimming pools in the close neighbourhood of the chosen leisure centre were included in the study thereby avoiding any confounding by the geographical area. Also, to maximise the likelihood of high exposure to $\mathrm{NCl}_{3}$, the study was conducted in the winter time, when the pools' windows and roofs are usually closed. 
The overall participation rate for this study was $97 \%$. In general, no major differences existed in the working conditions between the two types of pools.

Written informed consent was given by all subjects. Information was obtained about age, working hours a day, working duration, and occupational history. Lifeguards who had experienced earlier exposure to substances known to affect the respiratory system were excluded from the study. Table 1 shows the characteristics of the exposed group before the study started.

EXPOSURE MONITORING

The current concentrations of chloramines in the pools' atmospheres were measured over periods of three to four hours with area samplers. The method used was described in detail elsewhere. ${ }^{2}$ Briefly, ambient air was aspirated through glass fibre filter paper $(\mathrm{GF} / \mathrm{C}$ Whatman, $37 \mathrm{~mm}$ diameter) impregnated with a solution of sodium carbonate and trioxide diarsenic, with small vacuum pumps (Dupont S-2500, Kennett Square, PA, USA) the flow rate of which was kept at $1.01 \mathrm{~min}^{-1}$. Next, the impregnated filter was desorbed in $10 \mathrm{ml}$ twice distilled water and the resulting solution passed through a cation exchange resin to eliminate carbonate, a substance which interferes with the chloride analysis. Finally, the chloramine content of the solution was measured by liquid chromatography. By this method, $\mathrm{NCl}_{3}$ accounts for around $90 \%$ of measured chloramines, the remaining $10 \%$ being represented by monochloramines and dichloramines, as well as oxidant forms of chloride. ${ }^{2}$

Given the static character of the lifeguards' task, no individual atmospheric samples were carried out. Instead, area samplers were placed at various points around the pool where the lifeguards used to stay during the workshift. For each pool, the concentration of $\mathrm{NCl}_{3}$ was calculated as the mean of all measurements obtained at these points. This mean value was assigned individually to all lifeguards in the pool in question to yield the measured exposure index. Moreover, for each lifeguard, a cumulative exposure index was obtained by multiplying the measured exposure index by the duration of employment. Cumulative exposure in previous pools was estimated by multiplying the duration of work with the mean exposure concentration of the public or leisure swimming pools as applicable.

\section{RESPIRATORY HEALTH}

Medical history

Detailed histories of respiratory diseases and smoking habits were recorded with a two part questionnaire. The first was a modified version of the European Coal and Steel Community questionnaire on respiratory symptoms ${ }^{3}$ which was given by an experienced physician. The questionnaire emphasised the past and present personal and family histories of cough, phlegm, asthma, wheezing, and dyspnoea.

Chronic bronchitis - Chronic bronchitis was defined as cough and phlegm for at least three
Table 1 Anthropometric characteristics, smoking habits, and duration of exposure of lifeguards $(n=334)$ working in public and leisure centre swimming pools (mean (SD))

\begin{tabular}{lcr}
\hline Variables & Men & Women \\
\hline $\mathrm{n}$ & 256 & 78 \\
Age (y) & $36(9)$ & $32(7)$ \\
Height (cm) & $176(7)$ & $166(6)$ \\
Weight (kg) & $76(10)$ & $61(7)$ \\
Smoking habits: & $97(38)$ & $23(29)$ \\
$\quad$ Smokers (n (\%)) & $43(17)$ & $13(17)$ \\
$\quad$ Ex-smokers (n (\%)) & $116(45)$ & $42(54)$ \\
$\quad$ Non-smokers (n (\%)) & $11(9)$ & $11(8)$ \\
Tobacco consumption: & $12(12)$ & $2(3)$ \\
$\quad$ Smokers (pack-years) & $11(8)$ & $8(7)$ \\
$\quad$ Ex-smokers (pack-years) & & \\
Exposure (y) & &
\end{tabular}

months each year for not less than two successive years.

Chronic cough or phlegm-Chronic cough or phlegm was used to define subjects complaining of chronic cough or phlegm regardless of duration: thus, it encompassed both those subjects who fulfilled the criteria for chronic bronchitis and those who did not.

Bouts of bronchitis - Bouts of bronchitis was the term coined to define those subjects who answered affirmatively to the question: "Have you ever experienced an increase in the severity of cough and in the volume of sputum production of at least three weeks duration during the past three years"?

Dyspnoea on exertion - Dyspnoea on exertion was considered to be present when the subjects complained of breathlessness when walking up a slight hill.

Adult asthma-Adult asthma was defined as asthma which has been diagnosed by a physician at the age of 16 or older.

The second part of the questionnaire asked for specific symptoms, especially acute irritant symptoms, that the lifeguards attributed directly to their work. Irritant symptoms were considered to be present when the subject answered affirmatively to any of the questions "Have you ever had complaints at work of red (burning) (weary) eyes?"; "Have you ever had complaints at work of a runny (burning) nose?"; "Have you ever had complaints at work of a sore throat?" and; "Have you ever had complaints at work of a dry (irritant) cough?". A positive answer to any of these questions should be followed by a positive answer to the question: "Do these complaints disappear when you leave work (evenings, weekends, holidays)?".

Non-smokers were defined as subjects who had never regularly smoked one or more cigarettes a day or had smoked one or more cigarettes a day for less than one year. Current smokers were defined as subjects who reported regular smoking of one or more cigarettes a day for at least one year. Ex-smokers were subjects who reported smoking one or more cigarettes regularly in the past but who had stopped smoking at least one year before the study.

\section{Pulmonary function tests}

Spirometry was carried out by the same experienced technician (JPT), with an electronic spirometer (Spiro-Analyzer ST 300, Fukuda Sangyo Co. Tokyo, Japan). The following 
indices were obtained by having the subject expire forcefully and maximally after a maximal inspiratory manoeuvre: forced vital capacity (FVC), forced expiratory volume in one second $\left(\mathrm{FEV}_{1}\right)$, and maximal expiratory flows at various lung volumes. At baseline each subject performed at least three reproducible forced expiratory manoeuvres (within $5 \%$ for FVC and $\mathrm{FEV}_{1}$ ); thereafter only two reproducible curves were required. The curve with the highest sum of $\mathrm{FVC}+\mathrm{FEV}_{1}$ was used for statistical analysis. The results were expressed as the difference between the observed and predicted values of the European Respiratory Society. ${ }^{4}$

\section{Bronchial responsiveness}

As the examinations were carried out during workshifts, an abbreviated version of the methacholine bronchial challenge (MBC) test was used. ${ }^{5}$ The technique has been described previously. ${ }^{67}$ Three cumulative doses of methacholine $(0.5 \mu \mathrm{mol}, 2.5 \mu \mathrm{mol}$ and $7.5 \mu \mathrm{mol}-$ that is, $100 \mu \mathrm{g}, 500 \mu \mathrm{g}$, and $1500 \mu \mathrm{g}$, respectively) were given with an apparatus (Mediprom FDC 88 - Paris, France) delivering doses of $0.5 \mu \mathrm{mol}$ methacholine per breath. The system is equipped with a nebuliser De Vilbiss $5610 \mathrm{D}$ delivering particles $3 \mu$ in diameter. A noseclip was worn and the aerosol inhaled through the mouth slowly. Then the breath was held for five seconds. Spirometry was performed in the sitting position, before and three minutes after the inhalations of methacholine. The challenge test was discontinued either after the inhalation of the third dose of methacholine or if the $\mathrm{FEV}_{1}$ fell by $\geqslant 20 \%$ below the baseline value.

Subjects who experienced a fall in $\mathrm{FEV}_{1}$ of $\geqslant 20 \%$ or more were classified as having a positive MBC test $(\mathrm{MBC}+)$. As it could be anticipated that many subjects would fail to experience this specified response an additional non-censored index of responsiveness was computed, namely, the linear two point dose response slope as proposed by O'Connor and colleagues. ${ }^{8}$ The dose response slope was calculated as the ratio of the percentage fall in $\mathrm{FEV}_{1}$ at the last dose to the total dose of methacholine ( $\mu \mathrm{mol})$ given).

ETHICS

The study was approved by the local medical ethics committee.

STATISTICAL ANALYSIS

To be able to apply a multivariate analysis to the dose-response slope, a transformation to normalise the data was applied. The transformation $1 /\left(\%\right.$ fall $\left.\mathrm{FEV}_{1} / \mu \mathrm{mol}+2.5\right)$ in the family of shifted logarithmic and shifted inverse transformations was found to be optimal for a large unexposed population. ${ }^{6}$

The statistical analysis was carried out with the SAS statistical software. ${ }^{9}$ Multiple logistic regression analyses were used to assess the effect of the exposure on the symptoms while adjusting for smoking and age (for dyspnoea). Multiple linear regression was used to describe the effect of exposure on the baseline spirometric variables adjusted for smoking, and on the transformed dose-response slope adjusted for baseline $\mathrm{FEV}_{1}$ and age. We did not include smoking in this model as we found that this variable was unrelated to bronchial responsiveness. The stability of the variance and approximate linearities in the linear models were checked on residual plots.

\section{Results}

EXPOSURE ASSESSMENT

A total of 1262 samples were taken in the 63 pools. In public pools $(n=46)$ the mean (SD) $\mathrm{NCl}_{3}$ concentration of 860 measurements was $0.24(0.17) \mathrm{mg} / \mathrm{m}^{3}$. In leisure centre pools $(n=17)$ the mean (SD) concentration of 402 measurements was $0.67(0.37) \mathrm{mg} / \mathrm{m}^{3}$. Two public pools showed concentration values as high as $0.60 \mathrm{mg} / \mathrm{m}^{3}$ and two leisure centre pools had concentrations as low as $0.14 \mathrm{mg} / \mathrm{m}^{3}$. Thus our aim to achieve a wide range of exposures by matching leisure centres and public pools was reached with a few exceptions. However, as the aim of this study was to investigate the prevalence of symptoms as a function of exposures to $\mathrm{NCl}_{3}$ - which have been measured in every pool-the distinction between public and leisure pool was not relevant anymore. Consequently, four exposure classes were created, the limits of which were defined as the value allowing the stratification of the sample in four subgroups of about equal size. This was done for each exposure index as follows.

\section{Measured exposure index}

This is the average $\mathrm{NCl}_{3}$ concentration actually measured in each pool expressed in $\mathrm{mg} / \mathrm{m}^{3}$. The following exposures were taken for each subgroup: group $1, \mathrm{NCl}_{3}$ concentration $<0.14$ $\mathrm{mg} / \mathrm{m}^{3}$; group $2, \mathrm{NCl}_{3}$ concentration $0.14-0.22$ $\mathrm{mg} / \mathrm{m}^{3}$; group $3, \mathrm{NCl}_{3}$ concentration $0.22-0.50$ $\mathrm{mg} / \mathrm{m}^{3}$; and group $4, \mathrm{NCl}_{3}$ concentration $>0.50$ $\mathrm{mg} / \mathrm{m}^{3}$.

\section{Cumulative exposure index}

The cumulative exposure index was calculated for each lifeguard by multiplying the measured average $\mathrm{NCl}_{3}$ concentration in the pool by the number of working years $\left(\mathrm{y} \cdot \mathrm{mg} / \mathrm{m}^{3}\right)$. For the subjects who had worked previously in other pools, the estimated previous exposure was multiplied by the years spent in that pool and the result added to the first calculation. For this index, the $\mathrm{NCl}_{3}$ exposure limits defining the four subgroups were as follows: group a, $\mathrm{NCl}_{3}$ concentration $<0.58 \mathrm{y} \cdot \mathrm{mg} / \mathrm{m}^{3}$; group $\mathrm{b}, \mathrm{NCl}_{3}$ concentration $0.58-1.6 \mathrm{y} \cdot \mathrm{mg} / \mathrm{m}^{3}$; group $\mathrm{c}, \mathrm{NCl}_{3}$ concentration 1.6-3.12 y.mg/ $\mathrm{m}^{3}$; and group d, $\mathrm{NCl}_{3}$ concentration $>3.12 \mathrm{y} \cdot \mathrm{mg} / \mathrm{m}^{3}$.

RESPIRATORY AND IRRITANT SYMPTOMS Overall, the prevalence of chronic respiratory symptoms as a function of the cumulative exposure tended to be low, ranging from $0 \%$ for chronic bronchitis (groups a and d) and asthma (group c), to $14 \%$ for chronic cough or phlegm (group c, table 2). Conversely, the prevalence of irritant symptoms was rather high whatever the exposure index. For the measured exposure index, the observed rate ranged from $9.3 \%$ for tracheobronchial 
Table 2 Prevalence (\%) of chronic respiratory symptoms in 334 lifeguards stratified by exposure to nitrogen trichloride expressed in terms of the cumulative exposure index

\begin{tabular}{llllll}
\hline Symptom & $\begin{array}{l}\text { Group } \\
n=83\end{array}$ & $\begin{array}{l}\text { Group } \\
n=84\end{array}$ & $\begin{array}{l}\text { Groupc } \\
n=84\end{array}$ & $\begin{array}{l}\text { Groupd } \\
n=83\end{array}$ & p Value* \\
\hline Chronic bronchitis (n (\%)) & 0 & $5(5.9)$ & $1(1.2)$ & 0 & $-\dagger$ \\
Chronic cough or phlegm (n (\%)) & $7(8.5)$ & $2(2.4)$ & $14(16.7)$ & $5(6)$ & 0.87 \\
Bouts of bronchitis (n (\%)) & $6(7.2)$ & $9(10.7)$ & $10(11.9)$ & $5(6.1)$ & 0.86 \\
Dyspnoea (n (\%)) & $5(6.1)$ & $1(1.2)$ & $1(1.2)$ & $3(3.6)$ & 0.87 \\
Asthma (n(\%)) & $4(5.2)$ & $1(1.2)$ & 0 & $3(3.6)$ & 0.37
\end{tabular}

${ }^{\star}$ Logistic regression analysis.

† Small number of subjects precluded statistical analysis

Group $\mathrm{a}=$ exposure $<0.58 \mathrm{y} \mathrm{mg} / \mathrm{m}^{3}$; group $\mathrm{b}=$ exposure $0.58-1.6 \mathrm{y} \mathrm{mg} / \mathrm{m}^{3}$; group $\mathrm{c}=$ exposure $1.6-$ $3.12 \mathrm{y} \mathrm{mg} / \mathrm{m}^{3}$; group $\mathrm{d}=$ exposure $>3.12 \mathrm{y} \mathrm{mg} / \mathrm{m}^{3}$.

irritation in group 1 to $85.7 \%$ for eye irritation in group 4 (table 3). Similar results were found for the cumulative exposure index (table 3).

More importantly, the prevalences tended to increase with increasing exposures: for the measured exposure index, a significant concentration-response relation appeared for all symptoms whereas for the cumulative exposure index this was only the case for eye symptoms, and to a lesser extent, for nasal symptoms (table 3).

BASELINE LEVEL OF PULMONARY FUNCTION Table 4 shows the pulmonary function variables across the various classes of cumulative exposure separately for male and female lifeguards. Overall, the measured values exceeded the predicted ones for all variables in both groups. The observed excess FVC ranged from 0.5 to 0.7 in the two groups (table 4). In the male group, $\mathrm{FEV}_{1}$ tended to increase in proportion to FVC so their ratio remained around that predicted. By contrast, in the female group, $\mathrm{FEV}_{1}$ increased less obviously than FVC thus generating an $\mathrm{FEV}_{1} / \mathrm{FVC}$ ratio lower than that predicted. This finding should not mask the fact that both male and female lifeguards were rather "super" normal.

When the impact of exposures was assessed it seems that the trend toward increased lung capacity was less pronounced in lifeguards with the highest degree of exposure (group d, table $4)$.

BRONCHIAL RESPONSIVENESS

The MBC test was carried out in all exposed lifeguards $(n=334$, table 5$)$. The proportion of subjects with a positive MBC test (MBC+, $\mathrm{FEV}_{1}$ fall $\geqslant 20 \%$ ) was greater in female lifeguards than in male lifeguards. When the data were analysed for measured exposure, a high prevalence rate of positive MBC tests was noticed in female group 1. Both for female and male lifeguards, the frequency of positive MBC tests did not seem to be influenced by the degree of exposure whatever the index considered.

The mean dose-response slope of the female group as a whole was lower (steeper slope) than that of the male group but none changed significantly with the degree of measured or cumulative exposure. Again, when the data were expressed as measured exposures, a very low value of dose-response slope was noticed (steeper slope) for female group 1, a finding compatible with increased bronchial responsiveness in this group compared with the remaining female and male groups.

Table 3 Prevalence of irritation symptoms in 334 lifeguards stratified by exposure to nitrogen trichloride expressed in terms of the measured exposure index (groups 1-4) and the cumulative exposure index (groups $a-d$ )

\begin{tabular}{lllll}
\hline Exposure group $(n)$ & Eye $(n(\%))$ & Nose $(n(\%))$ & Sore throat $(n(\%))$ & Dry cough $(n(\%))$ \\
\hline Group 1 (86) & $43(50)$ & $10(11.6)$ & $14(16.3)$ & $8(9.3)$ \\
Group 2 (82) & $46(56.1)$ & $16(19.5)$ & $12(14.6)$ & $10(12.2)$ \\
Group 3 (75) & $47(62.6)$ & $21(28)$ & $20(26.7)$ & $16(21.3)$ \\
Group 4 (91) & $78(85.7)$ & $55(60.5)$ & $26(28.6)$ & $38(41.8)$ \\
p Value & 0.0001 & 0.0001 & 0.0143 & 0.0001 \\
Group a (83) & $42(50.6)$ & $18(21.7)$ & $12(14.5)$ & $12(14.5)$ \\
Group b (84) & $56(66.7)$ & $23(27.4)$ & $20(23.8)$ & $22(26.2)$ \\
Group c (84) & $54(64.3)$ & $29(34.5)$ & $19(22.6)$ & $18(21.8)$ \\
Group d (83) & $62(74.7)$ & $32(38.5)$ & $21(25.3)$ & 0.340 \\
p Value & 0.003 & 0.011 & 0.119 &
\end{tabular}

^Logistic regression analysis (linear trend).

Measured exposure:group $1=$ exposure $<0.14 \mathrm{mg} / \mathrm{m}^{3}$; group $2=$ exposure $0.14-0.22 \mathrm{mg} / \mathrm{m}^{3}$; group $3=$ exposure $0.22-0.50 \mathrm{mg} / \mathrm{m}^{3}$; group $4=$ exposure $>0.50 \mathrm{mg} / \mathrm{m}^{3}$. Cumulative exposure: group a=exposure $<0.58 \mathrm{y} \mathrm{mg} / \mathrm{m}^{3}$; group b=exposure $0.58-1.6 \mathrm{y} \mathrm{mg} / \mathrm{m}^{3}$; group $\mathrm{c}=$ exposure $1.6-3.12 \mathrm{y} \mathrm{mg} / \mathrm{m}^{3}$; group $\mathrm{d}=$ exposure $>3.12 \mathrm{y} \mathrm{mg} / \mathrm{m}^{3}$.

Table 4 Pulmonary function variable (observed values - predicted values (SD)) in male ( $n=256$ ) and female ( $n=78$ ) lifeguards stratified by exposure to nitrogen trichloride expressed in terms of the cumulative exposure index

\begin{tabular}{|c|c|c|c|c|c|}
\hline Variable & Group a & Group b & Group c & Groupd & $p$ Value ${ }^{\star}$ \\
\hline \multicolumn{6}{|l|}{ Male lifeguards: } \\
\hline $\mathrm{n}$ & 63 & 60 & 63 & 70 & - \\
\hline FVC (ml (SD)) & $677(560)$ & $688(508)$ & $633(516)$ & $492(621)$ & 0.05 \\
\hline $\mathrm{FEV}_{1}(\mathrm{ml}(\mathrm{SD}))$ & $474(505)$ & $484(552)$ & $508(465)$ & $333(539)$ & $0.25 \dagger$ \\
\hline $\mathrm{FEV}_{1} / \mathrm{FVC}(\%(\mathrm{SD}))$ & $0.63(5.39)$ & $0.37(5.79)$ & $2.20(4.51)$ & $1.15(4.65)$ & $0.30 \dagger$ \\
\hline $\mathrm{VE} \max _{50}(\mathrm{ml} / \mathrm{s}(\mathrm{SD}))$ & $168(1526)$ & $81(1513)$ & $390(1345)$ & $91(1585)$ & $0.90 \dagger$ \\
\hline \multicolumn{6}{|l|}{ Female lifeguards: } \\
\hline $\mathrm{n}$ & 20 & 24 & 21 & 13 & - \\
\hline $\mathrm{FVC}(\mathrm{ml}(\mathrm{SD}))$ & $632(436)$ & $493(379)$ & $667(396)$ & $410(518)$ & 0.50 \\
\hline $\mathrm{FEV}_{1}(\mathrm{ml}(\mathrm{SD}))$ & $384(332)$ & $231(378)$ & $442(298)$ & $311(471)$ & $0.80 \dagger$ \\
\hline $\mathrm{FEV}_{1} / \mathrm{FVC}(\%(\mathrm{SD})) \ddagger$ & $-0.96(5.28)$ & $-9.72(4.96)$ & $-7.62(5.19)$ & $-6.20(3.21)$ & $0.05 t$ \\
\hline $\mathrm{VE} \max _{50}(\mathrm{ml} / \mathrm{s}(\mathrm{SD})) \ddagger$ & $-98(984)$ & $-288(1015)$ & $-23(987)$ & $244(884)$ & $0.20 \dagger$ \\
\hline
\end{tabular}

*Linear regression.

†Adjusted for smoking.

$\ddagger$ Negative values are due to the fact that maximal expiratory flows increased less than static lung volume.

$\mathrm{FVC}$ =forced vital capacity; $\mathrm{FEV}_{1}=$ forced expiratory volume in one second.

Group a=exposure $<0.58 \mathrm{y} \mathrm{mg} / \mathrm{m}^{3}$; group $\mathrm{b}=$ exposure $0.58-1.6 \mathrm{y} \mathrm{mg} / \mathrm{m}^{3}$; group $\mathrm{c}=$ exposure $1.6-3.12 \mathrm{y} \mathrm{mg} / \mathrm{m}^{3}$; and group $\mathrm{d}=$ exposure $>3.12 \mathrm{y} \mathrm{mg} / \mathrm{m}^{3}$. 
Table 5 Methacholine bronchial challenge $(M B C)$ test in lifeguards $(n=334)$ stratified by measured exposure to nitrogen trichloride (groups $1-4)$ and by cumulative nitrogen trichloride exposure (groups a-d)

\begin{tabular}{|c|c|c|c|c|c|c|c|c|c|}
\hline Variable & Group 1 & Group 2 & Group 3 & Group 4 & Group a & Group b & Group c & Groupd & Total \\
\hline Male lifeguards (n) & 64 & 69 & 58 & 65 & 63 & 60 & 63 & 70 & 256 \\
\hline $\mathrm{MBC}-(\mathrm{n}(\%))$ & $7(11.7)$ & $11(15.9)$ & $13(22.4)$ & $4(6.1)$ & $10(17.3)$ & $12(20)$ & $8(12.7)$ & $5(7.1)$ & $35(13.7)$ \\
\hline \multicolumn{10}{|l|}{ Dose-response slope } \\
\hline$(1 /($ slope +2.5$))($ mean $(\mathrm{SD}))$ & $0.27(0.07)$ & $0.28(0.08)$ & $0.25(0.09)$ & $0.30(0.07)$ & $0.27(0.08)$ & $0.26(0.09)$ & $0.28(0.07)$ & $0.28(0.07)$ & $0.28(0.08)$ \\
\hline Female lifeguards ( $\mathrm{n}$ ) & 22 & 13 & 17 & 26 & 20 & 24 & 21 & 13 & 78 \\
\hline $\mathrm{MBC}+(\mathrm{n}(\%))$ & $13(59.1)$ & $4(30.8)$ & $1(5.9)$ & $4(15.4)$ & $5(25)$ & $10(41.7)$ & $6(28.6)$ & $1(7.7)$ & $22(28.2)$ \\
\hline \multicolumn{10}{|l|}{ Dose-response slope } \\
\hline$(1 /($ slope +2.5$))($ mean $(S D))$ & $0.19(0.09)$ & $0.24(0.11)$ & $0.29(0.07)$ & $0.27(0.07)$ & $0.25(0.08)$ & $0.22(0.01)$ & $0.27(0.10)$ & $0.28(0.07)$ & $0.25(0.09)$ \\
\hline
\end{tabular}

No significant relation was found between a positive MBC test and tracheobronchial irritation.

\section{Discussion}

Nitrogen trichloride is a highly irritant chloramine derived from the reaction between chlorine $\left(\mathrm{Cl}_{2}\right)$, used to disinfect swimming pool water, and nitrogenated substances of human origin-for example, sweat and urine. ${ }^{2}$ In open pools, $\mathrm{NCl}_{3}$ tends to dissipate in the atmosphere so it can hardly be considered a health hazard. However, in indoor pools - which are generally enclosed in a limited space-the continuous production of $\mathrm{NCl}_{3}$ may result in concentrations high enough to cause deleterious health effects. To the best of our knowledge this is the first study aimed at examining the relation between measured $\mathrm{NCl}_{3}$ concentrations, irritant and chronic symptoms, and bronchial responsiveness in the workforce at indoor pools.

In France, at present no specific recommendations exist about the threshold limit value for exposure to $\mathrm{NCl}_{3}$. Experiments carried out in mice by Gagnaire et al ${ }^{10}$ showed that this chloramine is an upper airway irritant as powerful as chlorine. Based upon concentrationresponse curves, these authors proposed a short term limit value of $1.5 \mathrm{mg} / \mathrm{m}^{3}$ and a long term limit value of $0.5 \mathrm{mg} / \mathrm{m}^{3}$ for $\mathrm{NCl}_{3}$. If these limits are acceptable for humans, it is reasonable to say that the quality of air in the public pools included in this study was generally good. Unfortunately, the same conclusions do not apply to the leisure centre pools because the $\mathrm{NCl}_{3}$ concentrations generally exceeded that limit for an eight hour workshift.

The greater $\mathrm{NCl}_{3}$ concentrations in leisure centre pools compared with public pools has been reported previously. ${ }^{211}$ It seems likely that this finding was caused by physical phenomena likely to enhance the dispersion of pollutants in the atmosphere of leisure centre pools. These include (a) higher water and air temperature; (b) recycling of air pollutants by use of air recycling devices; and (c) water surface disturbances produced mechanically - for example, waves). ${ }^{2}$ However, our finding of $\mathrm{NCl}_{3}$ concentrations in two leisure pools and two public pools suggest that factors other than those already suggested may be operating as well.

A high prevalence of eye and nose irritant symptoms was found both in female and male lifeguards which increased significantly with increasing $\mathrm{NCl}_{3}$ concentrations whatever the exposure index considered. Despite its cross sectional nature, this finding strongly supports the idea of a causal relation. This assumption is reinforced by the fact that our lifeguards worked essentially outside the water, in the surrounding area of the pool, thus making it unlikely that their symptoms were related to exposure to the pool water, a finding commonly found in pool bathers. ${ }^{12}$

By contrast, no relation was found between chronic respiratory symptoms and $\mathrm{NCl}_{3}$ concentrations, regardless of the exposure index. Although this finding points towards a lack of a causal relation it must be remembered that, because no information is available on the natural history of $\mathrm{NCl}_{3}$ exposure in humans, the possibility cannot be ruled out that our results merely reflect the fact that cumulative exposure in years might not have been sufficiently high.

It has long been known that champion swimmers have greater lung capacities than other athletes and non-swimmers. ${ }^{13}$ The most intuitive explanation for this finding is an increase in respiratory muscle strength or alveolar expansion in swimmers. Recently, Armour et $a l^{14}$ performed tests of mechanical lung function in small groups of elite swimmers, elite runners, and control subjects. They found total lung capacity, $\mathrm{FEV}_{1}$, and pulmonary diffusing capacity to be significantly greater in swimmers but found no differences in indices of lung elasticity; they concluded that the greater lung capacity of elite swimmers was not due to greater inspiratory muscle strength or alveolar distensibility but rather to an increased number of alveoli. Although our lifeguards are not elite swimmers they are much closer to this particular group of athletes than the general population; we can therefore imagine that their increased lung capacity is due to swimming itself. However, as pulmonary function variables have not been measured longitudinally, the possibility of self selection due to the healthy worker effect cannot be ruled out.

Most population studies have shown that adult women have greater bronchial responsiveness than adult men ${ }^{15-18}$ although contradictory findings have been reported by some investigators. ${ }^{19}{ }^{20}$ In this study, the mean prevalence of positive MBC tests in female lifeguards was twice as great as that in the male group (table 5). This result was independent of smoking habits and persisted after the data were adjusted for baseline $\mathrm{FEV}_{1}$ and age. Further inspection showed that this sex difference was due to a small group of 13 women whowhen the data were expressed in terms of measured exposure-were grouped together in group 1 (table 5). 
Factors invoked to explain the greater bronchial responsiveness in women include women's smaller airway calibre (adjusted for height and age), higher aerosol deposition in the women's airways (for similar aerosol exposure), and hormonal differences. ${ }^{21}$ Yet, had these factors been at the origin of the differences we found, they should have affected the female groups homogeneously.

At least two factors could be involved to explain the greater bronchial responsiveness of our 13 female lifeguards. Firstly, this could have been of racial origin. In one study, Sherman et $a l^{2}$ showed that black women had greater bronchial responsiveness than did white women and that such differences disappeared after adjustment for concentration of serum IgE and level of $\mathrm{FEV}_{1}$. However, all female lifeguards in this study were white. Secondly, increased bronchial responsiveness could have resulted from an intense exposure to $\mathrm{NCl}_{3}$ in the past followed by a move to cleaner workstations. This does not seem to be the case as six of them had always been employed in the same pool and have occupied the same, least exposed, work station.

In conclusion, this study showed that lifeguards of both sexes with exposure to $\mathrm{NCl}_{3}$ in indoor swimming pools are at risk of developing acute irritant symptoms. A relation between cumulative exposure to $\mathrm{NCl}_{3}$ and bronchial responsiveness to methacholine could not be formally shown; however, the possibility that responsive subjects selectively dropped out of the job cannot be ruled out. On the other hand, a relation between exposure to $\mathrm{NCl}_{3}$ and transient bronchial hyperresponsiveness - as indicated by the tracheobronchial complaints - seems plausible. Longitudinal studies are necessary to verify this hypothesis.

1 Hartemann P. Hygiènes des piscines. Pathologies et prévention. Le Concours Médical 1994;116:969-75.

2 Héry $M$, Hecht G, Gerber JM, et al. Exposure to chloramines in the atmosphere of indoor swimming pools. An. Occup Hyg 1995;39:427-39.
3 Minette A, Aresini G, Sanna-Randaccio F, et al. Ouestionnaire de la CECA pour l'étude des symptômes respiratoires, 3rd naire de la CECA pour l'étude des

4 Qd. Luxembourg: CECA, 1987. and forced respiratory flows. Report of the Working Party on Standardization of Lung Function Tests for the European Community for Coal and Steel. Eur.Respir 7 1993;6(suppl 16):5-40.

5 Gardner RM. Report of snowbird workshop on standardisation of spirometry. Am Rev Respir Dis 1979;119:831-8.

6 Bohadana $\mathrm{AB}$, Massin $\mathrm{N}$, Wild $\mathrm{P}$, et al. Respiratory symptoms and airway responsiveness in apparently healthy workers exposed to flour dust. Eur Respir F 1995;7:1070-6.

7 Massin N, Bohadana AB, Wild P, et al. Airway responsiveness, respiratory symptoms, and exposure to soluble oil mist in mechanical workers. Occup Environ Med 1996;53: $748-52$.

8 O'Connor G, Sparrow D, Taylor D, et al. Analysis of doseresponse curves to methacholine. An approach suitable for population studies. Am Rev Respir Dis 1987;128:1412-7.

population studies. Am Rev Respir Dis 1987;128:1412-7.
9 SAS Institute. SAS/SAT user's guide, version 6, 4th ed. Vol 2. SAS Institute. SAS/SAT user's guide,
Cary, NC: SAS Institute, 1989:846.

10 Gagnaire F, Azim S, Bonnet P, et al. Comparison of the sensory irritation response in mice to chlorine and nitrogen trichloride. J Appl Toxicol 1994;14:405-9.

11 Lawrence $M$. Swimming pool with waves: quality of air disturbed. Pollution Atmosphérique 1990;127:330-1.

12 Momas I, Brette F, Spinasse A, et al. Health effects of attending a public swimming pool: follow up of a cohort of pupils in Paris. $\mathcal{F}$ Epidemiol Community Health 1993;47: 464-8.

13 Andrew GM, Becklake M R, Guleria JS, et al. Heart and lung functions in swimmers and non-athletes during growth. F Appl Physiol 1972;32:245-51.

14 Armour J, Donnelly PM, Bye PTP. The large lungs of elite swimmers: an increased alveolar number? Eur Respir $\mathcal{f}$ 1993;6:237-47.

15 Cerveri I, Bruschi C, Zola MC, et al. Smoking habit and bronchial reactivity in normal subjects: a population based study. Am Rev Respir Dis 1989;140:191-6.

16 Bakke PS, Baste V, Gulsvik A. Bronchial responsiveness in a Norwegian community . Am Rev Respir Dis 1991;143:31722.

17 Peat JK, Salome MC, Berry G, et al. Relation of dose-response slope to respiratory symptoms and lung function in a population of adults living in Busselton, Western Australia. Am Rev Respir Dis 1992;146:860-5.

18 Paoletti P, Carrozzi L, Viegi G, et al. Distribution of Paoletti P, Carrozzi L, Viegi G, et al. Distribution of
bronchial responsiveness in a general population: effect of sex, age, smoking, and level of pulmonary function. Am $\mathcal{F}$ Respir Crit Care Med 1995;151:1770-7.

19 Burney PGJ, Britton JR, Chinn S, et al. Descriptive epidemiology of bronchial reactivity in an adult population: results from a community study. Thorax $1987 ; 42$ :38-44.

20 Rijcken B, Schouten JP, Weiss ST, et al. The relationship of non-specific bronchial responsiveness to respiratory symptoms in a random population sample. Am Rev Respir Dis 1987;132:62-8.

21 Zamel N. Threshold of airway response to inhaled methacholine in healthy men and women. Fournal of Applied Physiology Respiratory Environmental and Exercise Physiology 1984;56:129-32.

22 Sherman CB, Tollerud DJ, Hefner LJ, et al. Airway responsiveness in young black and white women. Am Rev Respir Dis 1993;148:98-102. 